\title{
SLAUGYTOJŲ PASIRENGIMAS SLAUGYTI PACIENTUS GYVENIMO PABAIGOJE: LIETUVOS SITUACIJA
}

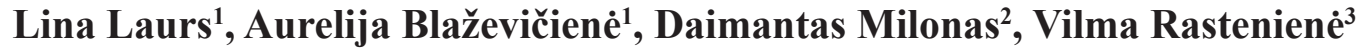 \\ ${ }^{1}$ Lietuvos sveikatos mokslu universiteto Slaugos ir rüpybos katedra, ${ }^{2}$ Lietuvos sveikatos moksly \\ universiteto Urologijos klinika, ${ }^{3}$ Kauno kolegijos Medicinos fakultetas
}

Raktažodžiai: slaugytojai, priežiūra gyvenimo pabaigoje, palengvinantys priežiūrą veiksniai, kliūtys, iškylančios slaugant pacientus.

\begin{abstract}
Santrauka
Paciento slauga jo gyvenimo pabaigoje apima daugeli aspektų: skausmo ir simptomų valdymą, kultūriškai jautrius klausimus, pagalbą pacientams, jų šeimų nariams mirimo procese ir išgyvenant netektį, etinius apsisprendimo klausimus. Pacientai ir jų šeimos nariai yra svarbūs partneriai, kurie dalyvauja planuojant pagalbą ir ligos gydymą.

Tyrimo tikslas - Lietuvos terapinio, chirurginio ir intensyvios terapijos skyrių slaugytojų pasirengimas slaugyti pacientus gyvenimo pabaigoje.

Tyrimo medžiaga ir metodas. Vienmomentinis kiekybinis tyrimas, atliktas septyniose didžiose Lietuvos ligoninèse. Tyrime dalyvavo stacionare dirbantys slaugytojai ( $\mathrm{N}=1055$; atsako dažnis 79,9 proc.). Rezultatai ir išvados. Pacientų priežiūrą gyvenimo pabaigoje palengvintų gerai organizuota darbo aplinka, reikiama dvasine pagalba pacientui bei išsaugotas orumas ir privatumas.

Pagrindinès kliūtys slaugant pacientus gyvenimo pabaigoje yra laiko trūkumas pokalbiams su pacientais, šeimos narių neturejjimas kur kreiptis psichologinès pagalbos sužinojus paciento diagnozę bei pikti šeimos nariai, trukdantys personalui.
\end{abstract}

\section{Ivadas}

Priežiūra paciento gyvenimo pabaigoje yra svarbus medicinos praktikos aspektas. Kiekvienas sveikatos priežiūros specialistas turi būti pasirengęs jautriai ir kompetentingai rūpintis mirštančiais pacientais ir jų šeimų nariais. Pacientai teisètai tikisi, kad sveikatos priežiūros specialistų komanda jais rūpinsis ir suteiks reikiamą medicininę pagalbą jų mirties valandą. Sveikatos priežiūros specialistai, siekdami tinkamai rūpintis mirštančiu pacientu, turi suprasti, kad paliatyvioji slauga apima paciento fizinius, psichosocialinius ir dvasinius poreikius ir kartais paliatyviems pacientams reikalinga skubi pagalba [1].

Paciento slauga jo gyvenimo pabaigoje apima daugeli aspektų: skausmo ir simptomų valdymą, kultūriškai jautrius klausimus, pagalbą pacientams, jų šeimų nariams mirimo procese ir išgyvenant netekti, etinius apsisprendimo klausimus. Literatūros apžvalga parodo, kad yra kliūtys, trukdančios atsiskleisti profesionalios slaugytojos kompetencijai. Sunkumai iškyla dèl mokymo programų apie mirtị ir mirimo procesą trūkumų, skirtingos sveikatos priežiūros politikos ir praktikos, ịvairaus gyvenimo pabaigos klausimų teisinio interpretavimo [2-4].

Pacientai ir jų šeimos nariai yra svarbūs partneriai, kurie dalyvauja planuojant pagalbą ir ligos gydymą. Slaugant pacientus gyvenimo pabaigoje būtini geri bendravimo ịgūdžiai. Bendravimas apima komunikaciją tarp paciento ir sveikatos priežiūros specialistų, taip pat tarp pacientų ir jų artimujų, tarp skirtingų pagalbą teikiančių sveikatos priežiūros specialistų bei tarnybų [5]. Paliatyviają pagalbą teikiantis sveikatos priežiūros specialistai susiduria su tikru iššūkiu, kai reikia suteikti sąžiningą, išsamią informaciją ir gerbti paciento bei jo šeimos viltị išgyventi nepaisant artejančios mirties. Gana dažnai gydytojai vengia pokalbių apie beviltišką paciento būklę, jie linkę sušvelninti esamą situaciją nutylèdami liūdnas prognozes, ar per daug optimistiškai kalbėdami su paciento šeima apie galimybes išgyventi [6]. Tokiu elgesiu medikai nepalieka šeimai laiko pasiruošti ar-

1 lentelè. Kronbacho alfa.

\begin{tabular}{|l|c|c|}
\hline & Cronbach's Alpha & Klausimų skaičius \\
\hline Požiūris & 0,721 & 18 \\
\hline Kliūtys & 0,777 & 11 \\
\hline $\begin{array}{l}\text { Nuo- } \\
\text { monè }\end{array}$ & 0,769 & 5 \\
\hline $\begin{array}{l}\text { Pritari- } \\
\text { mas }\end{array}$ & 0,634 & 6 \\
\hline
\end{tabular}


timojo mirčiai ir kokybiškai praleisti su juo likusị laiką. Kartais paciento šeima nepriima gydytojo jiems sakomos informacijos apie blogas paciento sveikatos prognozes ir trukdo slaugytojui prižiūretti pacientą neadekvačiai vertindami situaciją [7].

Dažnai slaugytojai, esantys arčiausiai paciento, paliekami patys spręsti, ką ir kada sakyti, o tai sudaro galimybę paprieštarauti gydytojo išsakytiems teiginiams ir sukelti paciento ir /ar jo artimųjų nepasitenkinimą [8]. Priimti sprendimą dèl intensyvaus, bet neefektyvaus gydymo nutraukimo yra sudetinga. Dažnai paciento būklès blogèjimą gydytojai linkę priimti kaip savo asmenini pralaimèjimą [6]. Sveikatos priežiūros specialistai turi suvokti, kad mirtis - tai gyvenimo dalis, o ne nesėkmè. Dèl ligos sunkumo ir gydymo pobūdžio, terminalinès būklès pacientams būna sunku išreikšti savo norus, todèl sprendimą tenka priimti šeimos nariams, o jie gana dažnai nesutaria, kokia priežiūra tinkamiausia. Ir šeimos nariams, ir sveikatos priežiūros specialistams emociškai sunku atsisakyti gydomosios priežiūros. Sveikatos priežiūros specialistai dažnai patiria paciento artimujų spaudimą nenutraukti gydymo, nors jis jau nebeduoda naudos, tik ilgina kančią [9]. Viena iš didžiausių problemu apsisprendžiant dèl gydymo nutraukimo tai neapibrèžtumas, kada pradèti pokalbị apie gyvenimo pabaigą su paciento artimaisiais. Slaugytojai ir gydytojai nuogąstauja, kad gali atimti vilti, jei medicinos darbuotojai per anksti priims klaidingą sprendimą [10]. Kitas veiksnys, apsunkinantis diskusiją apie gyvenimo pabaigą - tai aiškumo trūkumas, kokius vaidmenis turètų atlikti ịvairūs sveikatos priežiūros specialistai.

Deja, sveikatos priežiūros specialistai jaučiasi turintys nepakankamai žinių apie paciento priežiūrą gyvenimo pabaigoje. Jie pritaria, kad gyvenimo pabaigoje esančio paciento slaugymo ir žinių, kaip elgtis su gedinčia šeima, trūkumas yra rimta kliūtis užtikrinti kokybišką priežiūrą.

Mūsų tyrimo tikslas - atskleisti Lietuvos terapinio, chirurginio ir intensyvios terapijos skyrių slaugytojų pasirengimą slaugyti pacientus gyvenimo pabaigoje.

2 lentelè. Slaugytojų socialinès ir demografinès charakteristikos.

\begin{tabular}{|c|c|c|c|c|c|c|}
\hline & \multicolumn{3}{|c|}{ Skyrių profiliai } & \multicolumn{3}{|c|}{ Chi kvadrato testas } \\
\hline & $\begin{array}{l}\text { Terapijos } \\
\text { skyriai }\end{array}$ & $\begin{array}{l}\text { Chirurgijos } \\
\text { skyriai }\end{array}$ & $\begin{array}{c}\text { Intensyvios } \\
\text { terapijos } \\
\text { skyriai } \\
\end{array}$ & \multirow{2}{*}{$\begin{array}{c}\text { Chi } \\
\text { kva- } \\
\text { drato } \\
\text { reikšmė }\end{array}$} & \multirow{2}{*}{$\begin{array}{l}\text { Lais- } \\
\text { vès } \\
\text { laips- } \\
\text { niai }\end{array}$} & \multirow[t]{2}{*}{$\begin{array}{l}\mathbf{p} \\
\text { reikš- } \\
\text { mé }\end{array}$} \\
\hline & $\mathrm{N}(\%)$ & $\mathrm{N}(\%)$ & $\mathrm{N}(\%)$ & & & \\
\hline \multicolumn{7}{|l|}{ Amžius } \\
\hline I gr. (iki 44 m.) & $142(27,5 \%)$ & $103(29,9 \%)$ & $104(53,3 \%)$ & \multirow{4}{*}{49,346} & \multirow{4}{*}{4} & \multirow{4}{*}{0,000} \\
\hline II gr. $(44-50 \mathrm{~m})$. & $190(36,8 \%)$ & $125(36,3 \%)$ & $59(30,3 \%)$ & & & \\
\hline III gr. (> $50 \mathrm{~m})$. & $184(35,7 \%)$ & $116(33,7 \%)$ & $32(16,4 \%)$ & & & \\
\hline Iš viso & $516(100,0 \%)$ & $\begin{array}{c}344 \\
(100,0 \%)\end{array}$ & $\begin{array}{c}195 \\
(100,0 \%)\end{array}$ & & & \\
\hline \multicolumn{7}{|l|}{ Išsimokslinimas } \\
\hline Aukštasis universitetinis & $51(9,9 \%)$ & $43(12,5 \%)$ & $21(10,8 \%)$ & \multirow{4}{*}{26,361} & \multirow{4}{*}{4} & \multirow{4}{*}{0,000} \\
\hline $\begin{array}{l}\text { Aukštasis neuniversiteti- } \\
\text { nis (kolegija) }\end{array}$ & $201(39,0 \%)$ & $132(38,4 \%)$ & $112(57,4 \%)$ & & & \\
\hline Medicinos mokykla & $264(51,2 \%)$ & $169(49,1 \%)$ & $62(31,8 \%)$ & & & \\
\hline Iš viso & $516(100,0 \%)$ & $\begin{array}{c}344 \\
(100,0 \%)\end{array}$ & $\begin{array}{c}195 \\
(100,0 \%)\end{array}$ & & & \\
\hline \multicolumn{7}{|l|}{ Šeiminė padėtis } \\
\hline $\begin{array}{l}\text { Ištekèjusi/ vedęs/ ìsiparei- } \\
\text { gojęs (-usi) be santuokos }\end{array}$ & $326(63,2 \%)$ & $215(62,5 \%)$ & $127(65,1 \%)$ & \multirow{5}{*}{5,889} & \multirow{5}{*}{6} & \multirow{5}{*}{0,436} \\
\hline Išsiskyręs/išsituokusi & $96(18,6 \%)$ & $54(15,7 \%)$ & $25(12,8 \%)$ & & & \\
\hline Nevedęs/netekèjusi & $67(13,9 \%$ & $58(16,9 \%)$ & $31(15,9 \%)$ & & & \\
\hline Našlys (- è) & $27(5,2 \%)$ & $17(4,9 \%)$ & $12(6,2 \%)$ & & & \\
\hline Iš viso & $516(100,0 \%)$ & $\begin{array}{c}344 \\
(100,0 \%)\end{array}$ & $\begin{array}{c}195 \\
(100,0 \%)\end{array}$ & & & \\
\hline \multicolumn{7}{|c|}{ Dirba slaugytojos pareigose } \\
\hline $0-5 \mathrm{~m}$. & $48(9,3 \%)$ & $38(11,0 \%)$ & $28(14,4 \%)$ & \multirow{6}{*}{57,572} & \multirow{6}{*}{8} & \multirow{6}{*}{0,000} \\
\hline $6-15 \mathrm{~m}$ & $59(11,4 \%)$ & $32(9,3 \%)$ & $52(26,7 \%)$ & & & \\
\hline $16-25 \mathrm{~m}$ & $126(24,4 \%)$ & $91(26,5 \%)$ & $56(25,9 \%)$ & & & \\
\hline $26-31 \mathrm{~m}$ & $143(27,7 \%)$ & $90(26,2 \%)$ & $39(20,0 \%)$ & & & \\
\hline$>31 \mathrm{~m}$ & $140(27,1 \%)$ & $93(27,0 \%)$ & $20(10,3 \%)$ & & & \\
\hline Iš viso & $516(100,0 \%)$ & $\begin{array}{c}344 \\
(100,0 \%) \\
\end{array}$ & $\begin{array}{c}195 \\
(100,0 \%) \\
\end{array}$ & & & \\
\hline \multicolumn{7}{|l|}{ Darbo pamaina } \\
\hline Rytinè & $127(24,6 \%)$ & $67(19,5 \%)$ & $15(7,7 \%)$ & \multirow{5}{*}{70,647} & \multirow{5}{*}{6} & \multirow{5}{*}{0,000} \\
\hline Popietinè & $5(1,0 \%)$ & $2(0,6 \%)$ & $0(0,0 \%)$ & & & \\
\hline Naktinè & $83(16,1 \%)$ & $37(10,8 \%)$ & $3(1,5 \%)$ & & & \\
\hline Mišri & $301(58,3 \%)$ & $238(69,2 \%)$ & $177(90,8 \%)$ & & & \\
\hline Iš viso & $516(100,0 \%)$ & $\begin{array}{c}344 \\
(100,0 \%)\end{array}$ & $\begin{array}{c}195 \\
(100,0 \%) \\
\end{array}$ & & & \\
\hline \multicolumn{7}{|l|}{ Darbo krūvis } \\
\hline Iki 1 etato & $6(1,2 \%)$ & $8(2,3 \%)$ & $3(1,5 \%)$ & \multirow{4}{*}{31,223} & & \\
\hline 1 etatas & $416(80,6 \%)$ & $251(73,0 \%)$ & $119(61,0 \%)$ & & & \\
\hline$>1$ etatas & $94(18,2 \%)$ & $85(24,7 \%)$ & $73(37,4 \%)$ & & 4 & 0,000 \\
\hline Iš viso & $516(100,0 \%)$ & $\begin{array}{c}344 \\
(100,0 \%)\end{array}$ & $\begin{array}{c}195 \\
(100,0 \%) \\
\end{array}$ & & & \\
\hline
\end{tabular}


Pacientas turi būti aprūpintas visomis pragulų profilaktikos priemonemis ir priežiūra

Pacientas turi teisę $i$ orią ir neskausmingą mirtị

Pacientui visada turétų būti suteikta galimybè atlikti paskutinius religinius ritualus

Nutraukus intensyvų gydymą, pacientas ir toliau turètų gauti jo poreikius atitinkančią slaugą ir priežiūrą

Turetų būti išsaugotas paciento privatumas

Kenčiančiam nuo nepagydomos ligos pacientui tikslinga skirti optimalu kiekị skausmą malšinančių medikamentų, nors tai ir pagreitintų jo mirtị

Sveikatos priežiūros specialistams, dirbantiems su itin sunkios būklès pacientais ir dažnai susiduriantiems su mirtimi, reikia psichologinès pagalbos

Kai kurie pacientai gali būti nušalinami nuo sprendimu dèl ju gydymo ir slaugos prièmimo, nes abejojama jų sugebejjimu vertinti situaciją

Pacientai turi teisę atsisakyti gydymo, nors toks sprendimas taptų jų mirties priežastimi

Šeimai ir artimiesiems neturètų būti ribojamas paciento lankymo laikas ir trukmè

Pokalbiai su gydytojais apie paciento gyvenimo pabaigos problemu sprendimą daro teigiamą įtaką slaugytojų pasitenkinimui darbu

Paciento gyvenimo pabaigoje turètų būti tęsiamas dirbtinis maitinimas

Slaugytojai turi pakankamai žinių apie savo pacientus, kad galètų kompetentingai spręsti ko jie pageidautụ

Jūs jaučiatès psichologiškai pasiruošę spręsti problemas, iškylančias slaugant pacientus gyvenimo pabaigoje

Pokalbiai su paciento šeimos nariais apie paciento gyvenimo pabaigos problemų sprendimą daro teigiamą ịtaką slaugytojų pasitenkinimui darbu

Paciento sąmonè neturètų būti pastoviai slopinama raminančiais vaistais

Slaugytojai turi paisyti paciento norų, net jei jie prieštarauja jụ pačių isitikinimams

Lanky tojų skaičius prie paciento lovos neturètų būti apribotas

(1)

$$
0 \%
$$

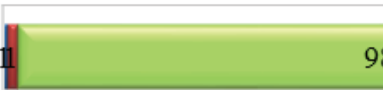

98

\section{6}

96
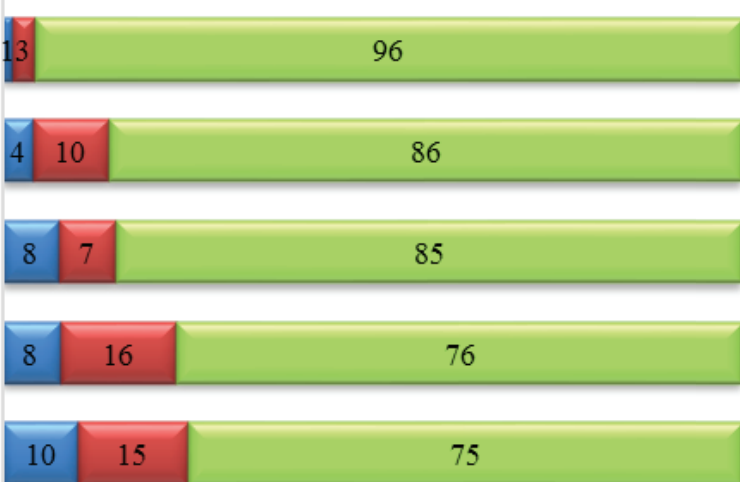

$18 \quad 76$
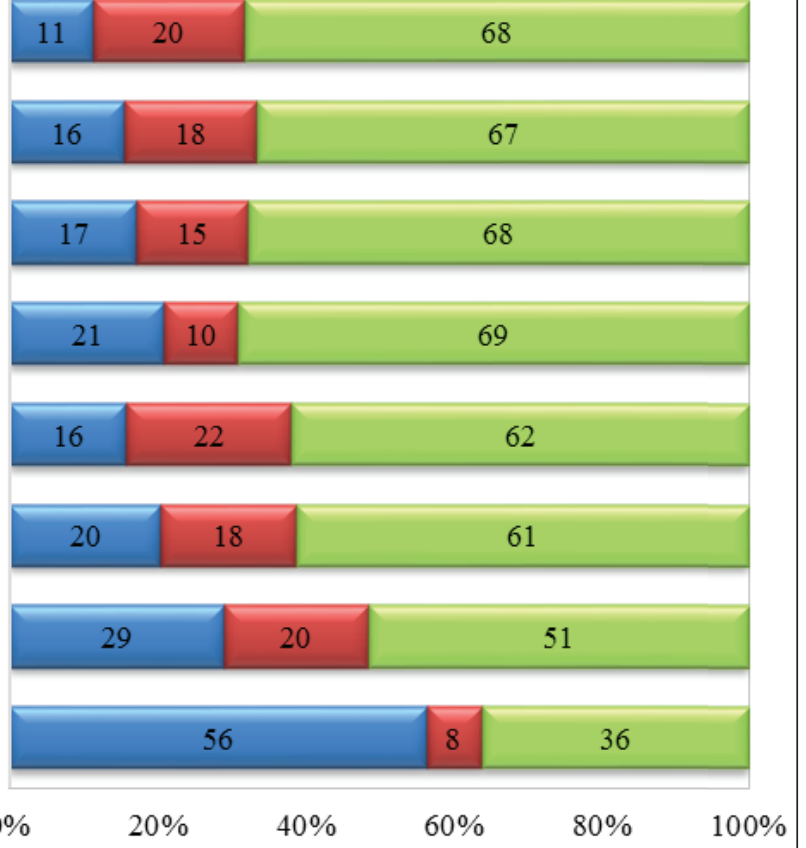

@Nesutinku $\square$ Neturiu nuomonès $\square$ Sutinku

1 pav. Bendras slaugytojų požiūris ị pacientų priežiūrą gyvenimo pabaigoje. 
3 lentelè. Kliūčių, kylančių slaugant pacientus gyvenimo pabaigoje, vertinimas priklausomai nuo skyriaus.

\begin{tabular}{|c|c|c|c|c|c|c|c|}
\hline \multirow{3}{*}{ Teiginys } & \multirow{3}{*}{$\begin{array}{l}\text { Atsaky- } \\
\text { mai }\end{array}$} & \multicolumn{3}{|c|}{$\begin{array}{c}\text { Atsakymų pasiskirstymas } \\
\text { pagal skyrių, kuriame dirba } \\
\text { slaugytojas (proc.) }\end{array}$} & \multicolumn{3}{|c|}{ Chi kvadrato testas } \\
\hline & & $\begin{array}{l}\text { Terapi- } \\
\text { jos sky- } \\
\text { riai }\end{array}$ & $\begin{array}{l}\text { Chirur- } \\
\text { gijos } \\
\text { skyriai }\end{array}$ & $\begin{array}{l}\text { Inten- } \\
\text { syvios } \\
\text { terapijos } \\
\text { skyriai } \\
\end{array}$ & \multirow[t]{2}{*}{$\begin{array}{l}\text { Chi } \\
\text { kva- } \\
\text { drato } \\
\text { reikšmè }\end{array}$} & \multirow[t]{2}{*}{$\begin{array}{l}\text { Laisvès } \\
\text { laips- } \\
\text { niai }\end{array}$} & \multirow[t]{2}{*}{$\begin{array}{l}\text { p reikš- } \\
\text { mé }\end{array}$} \\
\hline & & $\mathrm{N}=516$ & $\mathrm{~N}=344$ & $\mathrm{~N}=195$ & & & \\
\hline \multirow{3}{*}{$\begin{array}{l}\text { Labai dažnai neužtenka laiko } \\
\text { pokalbiams su pacientais } \\
\text { apie jų pageidavimus spren- } \\
\text { džiant gyvenimo pabaigos } \\
\text { problemas }\end{array}$} & Nesutinku & $9,3 \%$ & $9,6 \%$ & $9,7 \%$ & \multirow{3}{*}{12,17} & \multirow{3}{*}{4} & \multirow{3}{*}{0,016} \\
\hline & $\begin{array}{c}\text { Neturiu } \\
\text { nuomonès }\end{array}$ & $6,4 \%$ & $7,8 \%$ & $14,4 \%$ & & & \\
\hline & Sutinku & $84,3 \%$ & $82,6 \%$ & $75,9 \%$ & & & \\
\hline \multirow{3}{*}{$\begin{array}{l}\text { Šeima, sužinojusi apie pa- } \\
\text { ciento diagnozę, neturi kur } \\
\text { kreiptis dėl psichologinès } \\
\text { pagalbos }\end{array}$} & Nesutinku & $16,3 \%$ & $9,0 \%$ & $6,7 \%$ & \multirow{3}{*}{20,428} & \multirow{3}{*}{4} & \multirow{3}{*}{0,000} \\
\hline & $\begin{array}{c}\text { Neturiu } \\
\text { nuomonès }\end{array}$ & $10,3 \%$ & $14,2 \%$ & $16,4 \%$ & & & \\
\hline & Sutinku & $73,4 \%$ & $76,7 \%$ & $76,9 \%$ & & & \\
\hline \multirow{3}{*}{$\begin{array}{l}\text { Šeima ir draugai, nuolat } \\
\text { kviečiantys slaugytoją su- } \\
\text { žinoti apie paciento būklę, } \\
\text { užuot pasiklausę informuoto } \\
\text { šeimos nario }\end{array}$} & Nesutinku & $12,6 \%$ & $9,6 \%$ & $6,2 \%$ & \multirow{3}{*}{12,398} & \multirow{3}{*}{4} & \multirow{3}{*}{0,015} \\
\hline & $\begin{array}{c}\text { Neturiu } \\
\text { nuomonės }\end{array}$ & $10,5 \%$ & $16,3 \%$ & $15,4 \%$ & & & \\
\hline & Sutinku & $76,9 \%$ & $74,1 \%$ & $78,5 \%$ & & & \\
\hline \multirow{3}{*}{$\begin{array}{l}\text { Slaugos žinių, kaip elgtis } \\
\text { su gedinčia paciento šeima, } \\
\text { trūkumas }\end{array}$} & Nesutinku & $33,3 \%$ & $24,4 \%$ & $26,7 \%$ & \multirow{3}{*}{10,654} & \multirow{3}{*}{4} & \multirow{3}{*}{0,031} \\
\hline & $\begin{array}{c}\text { Neturiu } \\
\text { nuomonès }\end{array}$ & $15,1 \%$ & $18,6 \%$ & $21,0 \%$ & & & \\
\hline & Sutinku & $51,6 \%$ & $57,0 \%$ & $52,3 \%$ & & & \\
\hline \multirow{3}{*}{$\begin{array}{l}\text { Gydytojai per daug optimis- } \\
\text { tiški kalba su paciento šeima } \\
\text { apie ligonio galimybes išgy- } \\
\text { venti }\end{array}$} & Nesutinku & $30,8 \%$ & $29,9 \%$ & $30,3 \%$ & \multirow{3}{*}{4,743} & \multirow{3}{*}{4} & \multirow{3}{*}{0,315} \\
\hline & $\begin{array}{c}\text { Neturiu } \\
\text { nuomonès }\end{array}$ & $23,3 \%$ & $21,8 \%$ & $29,2 \%$ & & & \\
\hline & Sutinku & $45,9 \%$ & $48,3 \%$ & $40,5 \%$ & & & \\
\hline & Nesutinku & $43,2 \%$ & $40,4 \%$ & $44,6 \%$ & & & \\
\hline $\begin{array}{l}\text { Gydytoja1 issisukineja ir } \\
\text { vengia kalbetis su pacientu } \\
\text { ir/ar i šeima }\end{array}$ & $\begin{array}{c}\text { Neturiu } \\
\text { nuomonès }\end{array}$ & $15,7 \%$ & $21,2 \%$ & $21,0 \%$ & 6,552 & 4 & 0,162 \\
\hline & Sutinku & $41,1 \%$ & $38,4 \%$ & $34,4 \%$ & & & \\
\hline Slaugytojos nuomonė apie & Nesutinku & $31,4 \%$ & $29,1 \%$ & $24,6 \%$ & & & \\
\hline $\begin{array}{l}\text { tiesioginę paciento priežiūrą } \\
\text { yra nepageidaujama, neverti- }\end{array}$ & $\begin{array}{c}\text { Neturiu } \\
\text { nuomonès }\end{array}$ & $11,2 \%$ & $14,2 \%$ & $17,4 \%$ & 6,628 & 4 & 0,157 \\
\hline nama ar nesvarstoma & Sutinku & $57,4 \%$ & $56,7 \%$ & $57,9 \%$ & & & \\
\hline Paciento šeima nepriima gy- & Nesutinku & $11,4 \%$ & $13,1 \%$ & $6,2 \%$ & & & \\
\hline $\begin{array}{l}\text { dytojo jiems sakomos infor- } \\
\text { macijos apie blogas paciento }\end{array}$ & $\begin{array}{c}\text { Neturiu } \\
\text { nuomonès }\end{array}$ & $11,4 \%$ & $12,8 \%$ & $16,9 \%$ & 9,186 & 4 & 0,057 \\
\hline sveikatos prognozes & Sutinku & $77,1 \%$ & $74,1 \%$ & $76,9 \%$ & & & \\
\hline Slaugytojui prižiūrèti pa- & Nesutinku & $5,2 \%$ & $4,1 \%$ & $5,6 \%$ & & & \\
\hline $\begin{array}{l}\text { cientą trukdo neadekvačiai } \\
\text { situaciją vertinantys paciento }\end{array}$ & $\begin{array}{c}\text { Neturiu } \\
\text { nuomonès }\end{array}$ & $2,7 \%$ & $5,8 \%$ & $7,2 \%$ & 9,191 & 4 & 0,057 \\
\hline artimieji & Sutinku & $92,1 \%$ & $90,1 \%$ & $87,2 \%$ & & & \\
\hline & Nesutinku & $10,3 \%$ & $7,3 \%$ & $12,8 \%$ & & & \\
\hline $\begin{array}{l}\text { Paciento seimos narıaı ne- } \\
\text { sutaria, kokia priežiūra yra } \\
\text { tinkamiausia }\end{array}$ & $\begin{array}{c}\text { Neturiu } \\
\text { nuomonès }\end{array}$ & $14,0 \%$ & $20,9 \%$ & $17,4 \%$ & 11,069 & 4 & 0,026 \\
\hline & Sutinku & $75,8 \%$ & $71,8 \%$ & $69,7 \%$ & & & \\
\hline & Nesutinku & $8,9 \%$ & $9,9 \%$ & $8,2 \%$ & & & \\
\hline $\begin{array}{l}\text { Slaugytoja susiduria su pik- } \\
\text { tais paciento šeimos nariais }\end{array}$ & $\begin{array}{c}\text { Neturiu } \\
\text { nuomonès }\end{array}$ & $3,3 \%$ & $6,7 \%$ & $7,2 \%$ & 7,542 & 4 & 0,110 \\
\hline & Sutinku & $87,8 \%$ & $83,4 \%$ & $84,6 \%$ & & & \\
\hline
\end{tabular}




\section{Tyrimo medžiaga ir metodai}

Tyrimo eiga ir imtis. Tyrimas buvo vykdomas Lietuvos septynių didžiausiųjų miestų ligoninėse: Respublikinėje Vilniaus universitetinèje ligoninėje, Všt Respublikinèje Kauno ligoninèje, Všt Respublikinèje Klaipėdos ligoninejje, Všț Respublikinejje Šiaulių ligoninėje, Všț Respublikinèje Panevėžio ligoninėje, Všl̨ Alytaus apskrities S. Kudirkos ligoninèje ir VšĮ Marijampolès ligoninejje. Tyrimo vykdymo metu visose septyniose ligoninèse dirbo 1376 slaugytojai. Tyrimo metu buvo išdalyta 1400 anketų, grąžintos užpildytos 1180 anketos, iš kurių tinkamai užpildytos 1055 (atsako dažnis 79,9 proc.).

Tyrimo instrumentas. Buvo naudotas prof. Renea L. Beckstrand klausimynas, skirtas įvertinti slaugymo kliūtis, veiksnius, palengvinančius slaugą gyvenimo pabaigoje bei požiūris ị slaugą gyvenimo pabaigoje [11]. Pagal Likerto (Likert) 5 balų skalę respondentams reikejo įvertinti teiginius, pažymint vieną iš penkių atsakymo variantų: nuo 1 - „Visiškai sutinku“ iki 5 - „Visiškai nesutinku“. Anketos skalių vidinis patikimumus buvo Kronbacho (Cronbach) alfa $=0,936$. Taip pat, kad klausimų grupėse naudotų skalių vidiniai patikimumai yra geri (1 lentelè).

Tyrimo etika. Gautas Kauno regioninio biomedicininių tyrimų Etikos komiteto leidimas atlikti biomedicinini tyrimą Nr. BE- 2-27 bei ligonių vadovų sutikimai atlikti tyrimą.

Tyrimo statistika. Duomenys apdoroti naudojant statistinès analizès paketą SPSS 24.0. Duomenų pasiskirstymui palyginti naudoti Kruskalio-Voliso (Kruskal-Wallis) testai. Nominalinių kokybinių duomenų analizei naudotas neparametrinis $\chi^{2}$ testas. Dviejų imčių pasiskirstymui palyginti naudotas Mano Vitney (Mann-Whitney) U testas. Visuose testuose pasirinktas 0,05 reikšmingumo lygmuo.

4 lentelė. Neefektyvaus ir/arba pačiam ligoniui nepakeliamo gydymo priežasčiu vertinimas priklausomai nuo skyriaus.

\begin{tabular}{|c|c|c|c|c|c|c|c|}
\hline \multirow{3}{*}{ Teiginys } & \multirow{3}{*}{$\begin{array}{l}\text { Atsaky- } \\
\text { mai }\end{array}$} & \multicolumn{3}{|c|}{ Skyrius } & \multicolumn{3}{|c|}{ Chi kvadrato testas } \\
\hline & & $\begin{array}{l}\text { Terapi- } \\
\text { jos }\end{array}$ & $\begin{array}{l}\text { Chirur- } \\
\text { gijos }\end{array}$ & $\begin{array}{l}\text { Inten- } \\
\text { syvios } \\
\text { terapi- } \\
\text { jos }\end{array}$ & \multirow[t]{2}{*}{$\begin{array}{l}\text { Chi } \\
\text { kva- } \\
\text { drato } \\
\text { reikšmè }\end{array}$} & \multirow[t]{2}{*}{$\begin{array}{c}\text { Laisvès } \\
\text { laips- } \\
\text { niai }\end{array}$} & \multirow[t]{2}{*}{$\underset{\text { reikšmé }}{\mathrm{p}}$} \\
\hline & & $\mathrm{N}=516$ & $\mathrm{~N}=344$ & $\mathrm{~N}=195$ & & & \\
\hline \multirow{3}{*}{$\begin{array}{l}\text { Dèl pacientų arti- } \\
\text { mųjų spaudimo }\end{array}$} & Nesutinku & $18,4 \%$ & $18,9 \%$ & $14,4 \%$ & \multirow{3}{*}{5,097} & \multirow{3}{*}{4} & \multirow{3}{*}{0,278} \\
\hline & $\begin{array}{c}\text { Neturiu } \\
\text { nuomonès }\end{array}$ & $16,1 \%$ & $19,2 \%$ & $22,1 \%$ & & & \\
\hline & Sutinku & $65,5 \%$ & $61,9 \%$ & $63,6 \%$ & & & \\
\hline \multirow{3}{*}{$\begin{array}{l}\text { Dèl dabartinès } \\
\text { sveikatos apsaugą } \\
\text { reglamentuojančios } \\
\text { ịstatyminès bazès } \\
\text { trūkumų }\end{array}$} & Nesutinku & $10,3 \%$ & $7,8 \%$ & $3,6 \%$ & \multirow{3}{*}{9,382} & \multirow{3}{*}{4} & \multirow{3}{*}{0,052} \\
\hline & $\begin{array}{c}\text { Neturiu } \\
\text { nuomonès }\end{array}$ & $25,2 \%$ & $28,5 \%$ & $26,7 \%$ & & & \\
\hline & Sutinku & $64,5 \%$ & $63,7 \%$ & $69,7 \%$ & & & \\
\hline \multirow{3}{*}{$\begin{array}{l}\text { Dèl pačių gydytojų } \\
\text { asmeninių nuostatų: } \\
\text { religinių, etinių, mo- } \\
\text { ralinių pažiūrų ir kt. }\end{array}$} & Nesutinku & $38,8 \%$ & $42,4 \%$ & $28,7 \%$ & \multirow{3}{*}{11,663} & \multirow{3}{*}{4} & \multirow{3}{*}{0,020} \\
\hline & $\begin{array}{c}\text { Neturiu } \\
\text { nuomonės }\end{array}$ & $32,8 \%$ & $29,4 \%$ & $33,8 \%$ & & & \\
\hline & Sutinku & $28,5 \%$ & $28,2 \%$ & $37,4 \%$ & & & \\
\hline \multirow{3}{*}{$\begin{array}{l}\text { Dèl visuomenèje } \\
\text { vyraujančios mirties } \\
\text { baimès }\end{array}$} & Nesutinku & $28,5 \%$ & $27,0 \%$ & $22,1 \%$ & \multirow{3}{*}{4,299} & \multirow{3}{*}{4} & \multirow{3}{*}{0,367} \\
\hline & $\begin{array}{c}\text { Neturiu } \\
\text { nuomonès }\end{array}$ & $24,4 \%$ & $28,2 \%$ & $28,2 \%$ & & & \\
\hline & Sutinku & $47,1 \%$ & $44,8 \%$ & $49,7 \%$ & & & \\
\hline \multirow{3}{*}{$\begin{array}{l}\text { Dèl gydytoju bai- } \\
\text { mès, jog nepadarè } \\
\text { visko dël paciento }\end{array}$} & Nesutinku & $34,5 \%$ & $39,8 \%$ & $30,8 \%$ & \multirow{3}{*}{6,042} & \multirow{3}{*}{4} & \multirow{3}{*}{0,196} \\
\hline & $\begin{array}{c}\text { Neturiu } \\
\text { nuomonès }\end{array}$ & $31,6 \%$ & $31,7 \%$ & $33,3 \%$ & & & \\
\hline & Sutinku & $33,9 \%$ & $28,5 \%$ & $35,9 \%$ & & & \\
\hline
\end{tabular}

\section{Rezultatai}

Socialinès-demografinès respondentų charakteristikos. Tyrime dalyvavusių slaugytojų amžiaus vidurkis buvo 45,8 $\pm 9,852$ metai, darbo stažo vidurkis $-23,4 \pm 11,085$ metai. Didžioji dalis respondentų buvo vedę / ištekèję $(\mathrm{N}=668 ; 63,3$ proc.). Taip pat dauguma respondentų buvo baigę medicinos mokyklą ( $\mathrm{N}=495 ; 46,9$ proc.). Aukštaji universitetinị išsilavinimą turèjo 10,9 proc. respondentų $(\mathrm{N}=115)$ (2 lentelè).

Slaugytojų požiūris ì pacientų priežiūrą gyvenimo pabaigoje. Mūsų tyrimo rezultatai atskleidè, kad didžioji dalis respondentų sutiko su teiginiais: „Pacientas turi būti aprūpintas visomis pragulu profilaktikos priemonemis ir priežiūra“; „Pacientas turi teisę ị orią ir neskausmingą mirtį“; „Pacientui visada turi būti suteikta galimybè atlikti paskutinius religinius ritualus“; „Nutraukus intensyvų gydymą, pacientas ir toliau turètu gauti jo poreikius atitinkančią slaugą ir priežiūrą̨“ bei „Turètų būti išsaugotas paciento privatumas“. Mažiau svarbiais veiksniais respondentai įvardijo lankytojų skaičiaus ribojimą prie paciento lovos bei kad slaugytojai turi paisyti paciento norų, net jei jie prieštarauja jų pačių įsitikinimams (1 pav.).

Kliūtys, kylančios slaugant pacientus gyvenimo pabaigoje. Savo tyrime analizavome, kokios kliūtys iškyla slaugant pacientus gyvenimo pabaigoje terapijos, chirurgijos ir intensyvios terapijos skyriuose. Kaip matome iš tyrimo duomenų, statistiškai reikšmingai dažniau terapijos skyriuose dirbantys slaugytojai, lyginant su chirurgijos bei intensyvios terapijos slaugytojais, teigè, kad labai dažnai neužtenka laiko pokalbiams su pacientais apie jų pageidavimus sprendžiant gyvenimo pabaigos problemas bei pokalbiams su paciento šeimos nariais, nesutariačiais, kokia priežiūra yra tinkamiausia $(\mathrm{p}<0,05)$. Tuo tarpu slaugytojai, dirbantys intensyvios terapijos skyriuose, teigè, kad priežiūrai gyvenimo pabaigoje trukdo 
šeimos neturejjimas kur kreiptis psichologinès pagalbos, sužinojus apie paciento diagnozę, bei nuolatiniai šeimos ir draugų teiravimaisi apie paciento būklę, užuot tai išgirdus iš šeimos narių (3 lentelè).

Taip pat analizavome, ką mano slaugytojai apie gydymą, kuris neatitinka realios paciento padeties, yra neefektyvus ar pačiam pacientui nepakeliamas. Tyrimo duomenys atskleidè, kad statistiškai reikšmingai dažniau slaugytojai, dirbantys, intensyvios terapijos skyriuose, teige, kad toks gydymas yra dèl pačių gydytojų asmeninių nuostatų $\left(\chi^{2}=11,663 ; \mathrm{df}=4\right.$; $\mathrm{p}=0,020)$ (4 lentelè).

\section{Diskusija}

Viena iš pagrindinių kliūčiu išlieka laiko trūkumas. Labai dažnai neužtenka laiko pokalbiams su pacientais apie jų pageidavimus sprendžiant gyvenimo pabaigos problemas. Slaugytojai turi per daug užduočių, kad turètų pakankamai laiko ịsiklausyti i paciento pageidavimus, pabendrauti su jo šeima, suvokti jų vertybes, lūkesčius, požiūrį. Kiekvieno paciento, išgyvenančio gyvenimo pabaigos periodą, problemos yra individualios, reikalaujančios demesio ir laiko ị jas įsigilinti. Slaugytojai, nors ir žinodami, jog jų buvimas prie paciento lovos nuramins ir paguos išeinantị, negali tam skirti pakankamai laiko, nes laukia kiti pacientai $[13,14]$. Šią problemą gilina ir personalo trūkumas [15].

Mūsų tyrimo duomenys atliepia užsienio autorių gautus rezultatus. Viena iš pagrindinių kliūčių slaugytojai ịvardijo laiko su pacientais trūkumą.

Slauga gyvenimo pabaigoje apima ne tik praktinę, bet ir emocinę pagalbą. Slaugytojai turi skatinti ir paciento šeimą dalyvauti pokalbiuose, išsakyti savo jausmus, kalbeti, pajuokauti, ar tiesiog sédèti šalia ir laikyti savo artimajį už rankos [16]. Atlikti tyrimai, nagrinejjantys terminalinių būklių pacientų šeimų patirti, atskleidè, kad visi patyre bejëgiškumą ir liūdesị, o informacijos ir emocinès paramos tikejjosi iš slaugytojų $[10,18]$. Kartais slaugytojos vengia užmegzti artimesnį kontaktą su pacientu jo gyvenimo pabaigoje, nes yra emociškai sunku artejjančios mirties fakto nepripažįstantiems pacientams pasakyti, kad negali niekuo jiems padèti, sunku, kai žmogus miršta. Mūsų tyrimo duomenys taip pat atskleidè, kad priežiūra gyvenimo pabaigoje palengvètų, jeigu šeimos nariams būtų suteikta psichologinè pagalba sužinojus apie artimojo diagnozę.

Dar vienas veiksnys, trukdantis priežiūrą gyvenimo pabaigoje, artimujų nesusitarimas dèl tolimesnio gydymo. Priimti sprendimą dèl intensyvaus, bet neefektyvaus gydymo nutraukimo yra sudètinga. Dažnai paciento būklès blogèjimą gydytojai linkę priimti kaip savo asmeninị pralaimèjimą $[4,19]$.

Dèl ligos sunkumo ir gydymo pobūdžio, terminalinès būklès pacientams būna sunku išreikšti savo norus, todèl sprendimą tenka priimti šeimos nariams, o jie gana dažnai nesutaria, kokia priežiūra tinkamiausia. Ir šeimos nariams, ir sveikatos priežiūros specialistams emociškai sunku atsisakyti gydomosios priežiūros. Gydytojai dažnai patiria paciento artimujų spaudimą nenutraukti gydymo, nors jis jau nebeduoda naudos, tik ilgina kančią [20]. Viena iš didžiausių problemų apsisprendžiant dèl gydymo nutraukimo - tai neapibrèžtumas, kada pradèti pokalbị apie gyvenimo pabaigą su paciento artimaisiais. Slaugytojos ir gydytojai nuogąstauja, kad gali atimti vilti, jei medicinos darbuotojai per anksti priims klaidingą sprendimą $[8,12]$.

Deja, sveikatos priežiūros specialistai jaučiasi turintys nepakankamai žinių apie paciento priežiūrą gyvenimo pabaigoje. Jie pritaria, kad gyvenimo pabaigoje esančio paciento slaugymo ir žinių, kaip elgtis su gedinčia šeima, trūkumas yra rimta kliūtis užtikrinti kokybišką priežiūrą.

Apibendrinant galima teigti, kad dažniausiai pasitaikančios kliūtys, slaugant pacientus gyvenimo pabaigoje, yra laiko, skirto profesionaliai slaugai, trūkumas; personalo stygius; bendravimo su kolegomis, pacientu ir/ar paciento artimaisiais problemos; i paciento norus ir poreikius neatsižvelgiant priimti intensyvaus gydymo sprendimai; žinių apie gyvenimo pabaigoje esančio paciento priežiūrą ir elgesị su gedinčia šeima trūkumas.

\section{Išvados}

1. Pacientų priežiūrą gyvenimo pabaigoje palengvintų gerai organizuota darbo aplinka, reikiama dvasinè pagalba pacientui bei išsaugotas orumas ir privatumas.

2. Pagrindinès kliūtys slaugant pacientus gyvenimo pabaigoje yra laiko trūkumas pokalbiams su pacientais, šeimos narių neturejjimas kur kreiptis psichologinès pagalbos sužinojus paciento diagnozę bei pikti šeimos nariai, trukdantys personalui.

\section{Literatūra}

1. Clarfield M, Gordon M, Markwell H, Alibhai Sh M H. Ethical issues in end of life geriatric care: the approach of three monotheistic religions - Judaism, Catholicism, and Islam. JAGS 2003;51:1149-1154.

https://doi.org/10.1046/j.1532-5415.2003.51364.x

2. Beckstrand LR, Rasmussen JR, Luthy KE, Heaston S. Emergency nurses' perception of department design as an obstacle to providing end of life care. J Emerg Nurs 2012; 38: e27-e32. https://doi.org/10.1016/j.jen.2011.12.019

3. Beckstrand LR, Kirchhof KT. Providing end - of - life care to patients: critical care nurses' perceived oabstacles and supportive behaviors. American Journal of Critical Care 2005; 14:395-403.

4. Reinke FL, Shannon ES, Engelberg R, Dotolo D, Silvestri AG, 
Curtis JR. Nurses' identification of important yet under utilized end of life care skills for patients with life limiting or terminal illnesses. Journal of Palliative Medicine 2010; 13: 756-759. https://doi.org/10.1089/jpm.2009.0423

5. Anselm HA, Palda V, Guest BC, McLean FR, Vachon M, Kelner $\mathrm{M}$, Lam-McCulloch J. Barriers to communication regarding end of life care: perspectives of care providers. Journal of Critical Care 2005; 20: 214-223.

https://doi.org/10.1016/j.jcrc.2005.05.012

6. Beckstrand R L, Callister L C, Kirchhoff K T. Providing a "good death": critical care nurses' suggestions for improving end of life care. American Journal of Critical Care 2006;15(1):38-45.

7. Latour J M, Fulbrook P, Albarran J W. EfCCNa survey: European intensive care nurses' attitudes and beliefs towards end of life care. Journal British Association of Critical Care Nurses 2009;3:110-121.

https://doi.org/10.1111/j.1478-5153.2008.00328.x

8. Wilkie D, Judge M, Wells J, Berkley I. Excellence in teaching end of life care. Nurs Health Care Perspect 2001;22:226-230.

9. Liaschenko J, Conner-Von SO, Peden-Mcalpine C. The "big picture": communicating with families about end of life care in intensive care unit. Dimensions of Critical Care Nursing 2009; 28: 224-231.

https://doi.org/10.1097/DCC.0b013e3181ac4c95

10. Gjeberg E, Lillemoen L, Forde R, Pederson R. End of life care communications and shared decision making in Norwegian nursing homes experiences and perspectives of patients and relatives. BMC Geriatr 2015; 15; 103. https://doi.org/10.1186/s12877-015-0096-y

11. Beckstrand RL, Collette J, Callister L, Luthy EK. Oncology nurses' obstacles and supportive behaviors in end of life care: providing vital family care. ONF 2012; 39:E398-406. https://doi.org/10.1188/12.ONF.E398-E406

12. Iglesias, MEL, Pascual C, Vallejo RB. Obstacles and helpful behaviors in providing end of life care to dying patients in intensive care units. Dimensions of Critical Care Nursing. 2013;32(2):96-106.

https://doi.org/10.1097/DCC.0b013e3182808429

13. Attia AK, Wafaa W, Kandeel NA. Critical care nurses' perception of barriers and supportive behaviors in end of life care. American Journal of Hospice \& Palliative Medicine 2012, 30(3) 297-304. https://doi.org/10.1177/1049909112450067

14. Gagnon J, Duggleby W. The provision of end of life care by medical surgical nurses working in acute care: a literature review. Palliat Support Care. 2014 Oct;12(5):393-408. https://doi.org/10.1017/S1478951513000965

15. Moawad A. Nurses' perception of obstacles and supportive behaviors in providing end of life care to critically ill pediatric patients. Journal of Biology, Agriculture and Healthcare 2013;3(2).
16. Heaston S, Beckstrand RL, A. Elaine Bond AE, Palmer SP. Emergency nurses' perceptions of obstacles and supportive behaviors in end of life care. J Emerg Nurs 2006;32:477-85. https://doi.org/10.1016/j.jen.2006.07.013

17. Beckstrand RL, Moore J, Callister L, Bond E. Oncology nurses' perceptions of obstacles and supportive behaviors at the end of life. ONF 2009; 36(4), 446-453.

https://doi.org/10.1188/09.ONF.446-453

18. Blaževičienė A, Newland JA, Čivinskienė V, Beckstrand RL. Oncology nurses' perceptions of obstacles and role at the end of life care: cross sectional survey. BMC Palliat Care 2017 Dec 19;16(1):74.

https://doi.org/10.1186/s12904-017-0257-1

19. Peičius E, Blaževičiene A, Kaminskas R. Are advance directives helpful for good end of life decision making: a cross sectional survey of health professionals. BMC Med Ethics 2017 Jun 5;18(1):40.

https://doi.org/10.1186/s12910-017-0197-6

20. Thorns A. Ethical and legal issues in end of life care. Clin Med 2010; 10 (3).

https://doi.org/10.7861/clinmedicine.10-3-282

\section{PREPARATION OF NURSES FOR THE CARE OF END OF LIFE PATIENTS: SITUATION OF LITHUANIA}

L.Laurs, A.Blaževičienė, D.Milonas, V.Rastenienė

Key words: nurses; care at the end of life, factors facilitating care, nursing barriers.

Summary

The nursing of the patient at the end of his life involves many aspects: from pain and symptom management, to managing culturally sensitive questions, providing help to patient's relatives and family members, in the process of death and losing their lives. Patients and their family members are important partners in planning the assistance and further treatment.

The aim of the study - to evaluate the readiness of nurses in Lithuanian Therapeutic, Surgical and Intensive Care units to provide care at the end of patient lives.

Methodology. One time quantitative study performed in seven major Lithuanian hospitals. Practicing nurses participated in the study $(\mathrm{N}=1055$; response rate was $79.9 \%)$.

Results. A well organized working environment, the necessary spiritual support to the patient, and the preservation of dignity and privacy would greatly influence end of life patient care.

The main obstacles to patient care at the end of life are shortage of time to talk to the patients, lack of family members to seek psychological help after finding out the patient's diagnosis and unappropriated interference by family members with the staff.

Correspondence to: aurelija.blazeviciene@1smuni.1t

Gauta 2018-10-05 